\title{
Scena prawdy dyskursywnej i postprawdy. "Fakty autentyczne" i fakty medialne we współczesnym teatrze polskim
}

\begin{abstract}
Dobrowolski Piotr, Scena prawdy dyskursywnej i postprawdy. "Fakty autentyczne" i fakty medialne we współczesnym teatrze polskim [Stage of discursive truth and post-truth. Reality, authenticity and media facts in contemporary Polish theatre]. „Przestrzenie Teorii” 30. Poznań 2018, Adam Mickiewicz University Press, pp. 167-186. ISSN 1644-6763. DOI 10.14746/pt.2018.30.8.

Theatre practitioners' statements relating to the notion of truth lead to the category of post-truth. Stage of discursive truth and post-truth article discusses theatre practice of engaging feelings, impressions and emotions to take precedence over interpretations, assessments and descriptions of facts. The article critically approaches using of media discourses in theatre in order to produce the imitation of truth. The author refers to Agnieszka Jakimiak's and Weronika Szczawińska's play Wojny, których nie przeżyłam [Wars I have not experienced] and other selected recent Polish plays and performances. The thesis connects the media-shaped image of Polish theatre art institution seen as an area of provocation with an experience of a viewer and an ontological status of an actor. This allows drawing a conclusion that theatre uses the category of truth instrumentally, as one of its repertoire's tools to provoke emotional reactions in the audience. Theatre performances allow one to explore the world, but also to co-create it. The theatre is a performative and cognitive sieve provoking and shaping experience that affects reality.
\end{abstract}

KEYWORDS: theatre, drama, performance, mass media, truth, post-truth, experience

„Świat miejscem prawdy” to hasło przewodnie odbywającej się w roku 2016 Olimpiady Teatralnej. Jarosław Fret, kurator Europejskiej Stolicy Kultury Wrocław 2016 ds. teatru, nawiązał nim do artykułu Jerzego Grotowskiego zatytułowanego Świat powinien być miejscem prawdy ${ }^{1}$, opublikowanego w „Dialogu” (nr 10) w roku 1979. W swoim tekście programowym, funkcjonującym jako rodzaj credo, Fret deklarował z przekonaniem: „Wierzę, że świat powinien być miejscem prawdy - teatr już nim jest"2. Wyznanie wiary kuratora, na co dzień będącego dyrektorem Instytutu im. J. Grotowskiego we Wrocławiu i liderem Teatru ZAR, skłania do zadawania pytań o implikowane w nim znaczenia. Interesująca wydaje się zarówno sugerowana pośrednio wizja „rzeczywistości” (rodzaj subiektywnej projekcji obrazu

${ }^{1}$ J. Grotowski, Świat powinien być miejscem prawdy, [w:] tegoż. Teksty zebrane, Warszawa 2012 , s. $618-623$.

${ }^{2}$ J. Fret, Teatr - credo Jarostawa Freta, <http://www.wroclaw2016.strefakultury.pl/ jaroslaw-fret> [dostęp: 1.10.2018]. 
realności), jak też wpływ, jaki na instytucję teatru ma rozumienie pojęcia prawdy. Mam wrażenie, że scena traktowana jest przez Jarosława Freta jako soczewka skupiająca impulsy pochodzące spoza uniwersum sztuki. Nie tylko sugeruje on potrzebę jednoznacznego opisu prawdy we współczesnym świecie, ale też odniesienie jej do teatru, co może mieć bardzo poważne konsekwencje dla postrzegania tej sztuki. Chociaż scena jest przestrzenią dla światów możliwych, można traktować ją także jako swoiste „zwierciadło natury" odbijające obraz otaczającej nas rzeczywistości.

Humanistyka, w przeciwieństwie do nauk ścisłych, których metodologie i systemy deskrypcji pozwalają na diagnozowanie zjawisk i zachodzących pomiędzy nimi zdarzeń z użyciem konkretnych, wymiernych parametrów i skal odniesienia, ma charakter dyskursywny. W praktykach i badaniach humanistycznych, a także w odniesieniu do twórczości artystycznej, akceptujemy relatywizm poznawczy, co z kolei wymusza subiektywne traktowanie kategorii prawdy. Obserwacja ta utrudnia oparcie w faktach, zbliżając komentatorów twórczości artystycznej do pozbawionej obiektywnego zakotwiczenia sfery pojęć takich jak przekonanie czy wiara. Równocześnie zaś właśnie przekonanie i wiara stanowia istotna, nienaruszalną i niedyskursywną wartość dla wszystkich tych, którzy skłonni są indywidualnie poszukiwać dzisiaj stabilności na wzburzonym morzu relatywizmu. $\mathrm{W}$ ich perspektywie naukowa i empiryczna prawda nie ma decydującego znaczenia, ponieważ ważniejsze od jej obiektywnej wartości staje się - wewnętrzne, motywowane afektywnie - jednostkowe przekonanie.

\section{Postprawda}

Instytut Badań Wojen Nieprzeżytych został powołany z woli stworzenia jednolitej, choć bogatej i choć urozmaiconej, polityki artystyczno-kulturalnej. Akt jego założenia jest reakcją na wszędobylskie wojenne narracje, przedwojenne lęki, prowojenne nastroje, powojenne antycypacje i wojenne obsesje, które opanowały zbiorowe wyobraźnie. Rada Instytutu jest w pełni świadoma ryzyka związanego z dopuszczeniem do władzy medialnego, informacyjnego, wizualnego, komunikacyjnego i artystycznego chaosu ${ }^{3}$.

Istniejące współcześnie, równoległe względem siebie lub przeplatające się wzajemnie popularne dyskursy, często pozostające w bezpośredniej zależności z dyskursami medialnymi, wprowadzają własne słowniki i składnię opisów świata. Modelują tak język, pośrednio wpływając na rzeczywistość. Ich użytkownicy często zakładają własną nieomylność, co staje się tau-

${ }^{3}$ A. Jakimiak, Wojny, których nie przeżyłam, scenariusz spektaklu w reżyserii Weroniki Szczawińskiej, Teatr Polski im. Hieronima Konieczki w Bydgoszczy, premiera 23.09.2015. Maszynopis udostępniony dzięki uprzejmości Teatru Polskiego w Bydgoszczy. 
tologicznym dowodem trafności własnych przeświadczeń i prawdziwości formułowanych sądów. W ten sposób w praktyce dyskursów publicznych znacznie częściej od prawdy pojawia się dzisiaj kategoria określana mianem postprawdy. Pojęcie to służy do opisania okoliczności, w których nie fakty, a emocje i osobiste przekonania wypowiadającej się osoby mają decydujący wpływ na sposób postrzegania przez nią rzeczywistości i tworzenia jej opisów. W angielskiej wersji językowej (post-truth) termin ten po raz pierwszy pojawił się w roku 1992, kiedy użyty został przez Steve'a Tesicha w artykule krytycznie odnoszącym się do amerykańskiego dyskursu politycznego opisującego konsekwencje I wojny w Zatoce Perskiej ${ }^{4}$. Zawarta w nim diagnoza zdaje się mieć dzisiaj szczególne znaczenie: „[...] we, as a free people, have freely decided that we want to live in some post-truth world"5. Mimo trafności stwierdzenia, że sami wybraliśmy swój los, decydując się na życie w świecie postprawdy, kolejne kilkanaście lat ani nie przyniosło krytycznego nastawienia wobec tej praktyki, ani nie przyczyniło się do wzrostu popularności samego terminu. Powrócił on do użycia w ostatniej dekadzie (około 2008 roku), jednak gwałtowna, frekwencyjną karierę rozpoczął dopiero pod koniec pierwszej połowy roku 2016 (oparte na monitoringu mediów statystyki prowadzone przez redaktorów Oxford English Dictionary mówią o znacznym, dochodzącym do $2000 \%$ wzroście obserwacji tego słowa w różnego typu publikacjach pomiędzy średnią z roku 2015 a połową maja 2016 roku$\left.^{6}\right)$.

Rosnąca popularność pojęcia, które wcześniej niemal nie pojawiało się poza ramami eseistyki naukowej i krytyki politycznej, sprowokowała redaktorów oksfordzkiego słownika do uznania postprawdy za słowo roku $2016^{7}$. Jako główny kontekst i przyczyna jego oszałamiającej kariery najczęściej wskazywany jest styl kampanii prezydenckiej w Stanach Zjednoczonych, która zakończyła się wyborczym zwycięstwem Donalda Trumpa ${ }^{8}$ (jak wyliczył portal „PolitiFact”, Trump, jako kandydat na prezydenta, operował postprawdą tak swobodnie, że w $69 \%$ swoich publicznych wypowiedzi w czasie kampanii rozmijał się z prawdą ${ }^{9}$ ). Skuteczność postprawdy potwierdziły też efekty kampanii przed referendum w sprawie wystapienia Wielkiej Brytanii

\footnotetext{
${ }^{4}$ S. Tesich, A Government of Lies, "The Nation" 1992, January 6/13, s. 12-13.

${ }^{5}$ „,[...] jako wolni ludzie, dobrowolnie zdecydowaliśmy, że chcemy żyć w świecie postprawdy", tamże, s. 13.

${ }^{6}<$ https://www.oxforddictionaries.com/press/news/2016/12/11/WOTY-16> [dostęp: 1.10.2018].

${ }^{7}$ Word of the Year 2016 is..., <https://en.oxforddictionaries.com/word-of-the-year/word-of-the-year-2016> [dostęp: 1.10.2018].

${ }^{8}$ M. Norman, Whoever wins the US presidential election, we've entered a post-truth world - there's no going back now, "The Independent Online", http://www.independent.co.uk/ voices/us-election-2016-donald-trump-hillary-clinton-who-wins-post-truth-world-no-going-back-a7404826.html> [dostęp: 1.10.2018].

${ }^{9}<$ http://www.politifact.com/personalities/donald-trump> [dostęp: 1.10.2018].
} 
z Unii Europejskiej czy rosyjska propaganda tłumacząca aneksję Krymu i odnosząca się do wojny na Ukrainie. W jednym z artykułów opublikowanych w brytyjskim tygodniku „The Economist” repertuar ten wzbogacony został o teorie spiskowe wskazujące na udział CIA w nieudanym przewrocie wojskowym w Turcji, a także o tezy sugerujące, że przyczyną katastrofy polskiego samolotu prezydenckiego pod Smoleńskiem był zamach ${ }^{10}$. Wszystkie wskazane odniesienia łączy to, że zwolennicy konkretnych poglądów i teorii wpływających na ocenę prezentowanych sytuacji nie opierają się na obiektywnych argumentach, rozumie, wiedzy naukowej ani empirycznych obserwacjach, a na własnych emocjach i wierze.

Wskazane precedensy nie zamykają listy przykładów stosowania postprawdy przez polityków, publicystów i nadawców medialnych, pragmatycznie wykorzystujących oczekiwania, przekonania i emocje odbiorców swoich komunikatów. W ich perspektywie masowy odbiorca to część „ogłupiałego stada”, o którym pisał Walter Lippmann, cytowany przez Noama Chomsky'ego w książce Media Control ${ }^{11}$ - zbiorowości poddawanej celowej manipulacji. Potwierdza to diagnoza oksfordzkich językoznawców, tłumaczących współczesne przykłady użycia przedrostka post w odniesieniu do postprawdy nie w kategoriach następstwa, uzupełniania czy dopowiadania centralnego, poprzedzanego przez niego terminu, a jako wskazanie, że uważany jest on za „nieważny i nieznaczący”12. Tak właśnie - jako nieważna i nieznacząca - traktowana jest prawda w erze postprawdy. Dodatkowo, próbując lepiej zrozumieć zasadę funkcjonowania tej praktyki, podkreślić trzeba także pragmatyczne zastosowanie wewnętrznych przeczuć, uprzedzeń i wcześniejszych przekonań jednostki, której poparcie jest właściwym celem polityków w systemach demokratycznych. Na łamach polskiej prasy zasadę tę tłumaczył Jakub Majmurek, pisząc w „Newsweeku”, że współczesny człowiek (,wyborca ery postprawdy”) nie szuka prawdziwej informacji, która pozwoliłaby mu weryfikować własne poglądy, a „potwierdzenia własnych emocji i uprzedzeń”"

$\mathrm{W}$ erze postprawdy odczucia przejmują kontrolę nad interpretacja, oceną i opisem faktów. Zasadę tę od dawna znają i wykorzystują artyści rozmaitych dziedzin twórczości, starający się prowokować afekty swoich odbiorców - widzów, czytelników, słuchaczy. Historia zna przypadki, kiedy emocje

${ }^{10}$ Post-truth politics. Art of the lie, "The Economist Online", <http://www.economist. $\mathrm{com} /$ news/leaders/21706525-politicians-have-always-lied-does-it-matter-if-they-leavetruth-behind-entirely-art?fsrc=scn/tw/te/pe/ed/artofthelie $>$ [dostęp: 1.10.2018].

${ }^{11}$ N. Chomsky, Media Control. The Spectacular Achievements of Propaganda, New York 2002, s. 16.

${ }^{12}$ Word of the Year 2016 is...

${ }^{13} \mathrm{~J}$. Majmurek, Post-prawda, czyli o świecie, w którym ciagle można wierzyć w zamach smoleński, <http://www.newsweek.pl/polska/spoleczenstwo/post-prawda-slowem-roku-2016-czymjest-post-prawda-i-jak-wplywa-na-polityke-,artykuly,401583,1.html> [dostęp: 1.10.2018]. 
widowni wylewały się poza przestrzeń fikcyjnego uniwersum teatralnego, wywierając bezpośredni wpływ na rzeczywistosść ${ }^{14}$. Z zależności występującej między interpretacja konkretnej prezentacji i emocjami jej adresatów zdawały sobie też sprawę Agnieszka Jakimiak i Weronika Szczawińska, kiedy w Teatrze Polskim w Bydgoszczy pracowały nad spektaklem zatytułowanym Wojny, których nie przeżytam. Nie dane było mi uczestniczyć osobiście w tym widowisku. Nie widziałem go i nie słyszałem kwestii wybrzmiewających na scenie. Jednak - podążając za pojawiającą się w jego tytule sugestią i działając w duchu postprawdy - powyżej, a także w dalszych częściach mojego artykułu - przywołuję fragmenty jego scenariusza, które służą mi jako artystyczne wprowadzenie do kolejnych części tego tekstu.

\section{Nius}

Domagam się zmiany statusu emocji i przyznania im pierwszorzędnej roli w badaniu wojen nieprzeżytych. Moja praca polega na upartym zadawaniu pytań. Jakich emocji wojennych doświadczasz w obliczu wojen, których nie przeżywasz? Dlaczego ich doświadczasz? Kto lub co wywołuje twój lęk? Kto i co wprawia cię w ekscytację? Czemu komuś współczujesz, czemu z kimś się identyfikujesz, czemu wydaje ci się, że wojna jest bardzo blisko albo bardzo daleko? ${ }^{15}$

Rozważania na temat wpływu mediów, a szczególnie tak zwanych nowych mediów ${ }^{16}$ na teatr prowadzone są nie od dzisiaj ${ }^{17}$. Najczęściej stawiane

${ }^{14}$ Najczęściej wspomniane przykłady takich efektów widowiska scenicznego to wybuch rewolucji belgijskiej w roku 1830, która miała rozpoczać się wraz z patriotycznym uniesieniem publiczności Niemej z Portici (La muette de Portici) - opery z muzyką Daniela Aubera oraz librettem Eugène’a Scribe'a i Germaina Delavigne'a - oraz wpływ Dziadów wyreżyserowanych przez Kazimierza Dejmka w Teatrze Narodowym na wydarzenia prowadzące do Marca 1968. Podobny mechanizm - wywoływania emocji podczas spektaklu teatralnego i wyprowadzania publiczności na ulicę - wykorzystywały grupy tworzące amerykańską kontrkulturę teatralna, a ostatnio, wracając do społecznych emocji polskiego społeczeństwa wywoływanych przez falę Czarnych Protestów - Wiktor Rubin, inscenizujący w październiku 2016 roku w Teatrze Polskim w Bydgoszczy tekst Jolanty Janiczak Żony stanu, dziwki rewolucji, a może i uczone białogłowy.

${ }^{15}$ A. Jakimiak, dz. cyt.

${ }^{16}$ „Warto zauważyć, iż w teorii mediów nie ma jednoznacznego stanowiska co do tego, czym są nowe media. Z jednej strony uważa się, iż wyznacznikiem powstania nowych mediów jest telewizja, a one same sa technikami pozyskiwania, przetwarzania i transmisji danych wprowadzonymi do obiegu później niż telewizja tradycyjna. Z drugiej mówi się, że przy próbach klasyfikowania nowych mediów należy stosować kryterium nośnika i interaktywności, ze wskazaniem, iż nowe media pozwalają na pełniejsze i nietradycyjne, tj. wymagające aktywnego udziału odbiorcy, wykorzystanie urządzeń elektronicznych”. M. Szpunar, Czym sq nowe media - próba konceptualizacji, „Studia Medioznawcze” 2008, 4 (35), s. 33.

${ }^{17}$ Zob. np. M. Błaszczak, Ekrany i lustra w polskim dramacie wspótczesnym, Poznań 2009; A. Duda, Performans na żywo jako medium i obiekt mediatyzacji, Toruń 2011; D. Sajew- 
w tym kontekście pytania odnoszą się do włączania w obręb widowisk scenicznych różnego rodzaju technik, narzędzi czy stylów komunikacji wykorzystujących inspiracje medialne. Dotyczą także praktyki przeszczepiania interaktywności czy technologii cyfrowych do teatru, gdzie wprowadzane sa zgodnie z wzorami wypracowanymi przez inne środki przekazu. Interesujący obszar badań obejmuje też związki pomiędzy teatralną komunikacją a dyskursami medialnymi, gdzie zwrot wpływu może ulegać częściowemu odwróceniu. W tym właśnie kontekście chciałbym wykorzystać wprowadzone wyżej pojęcie postprawdy, zdecydowanie odwracając najczęściej wskazywana zależność i - zamiast zastanawiać się nad bezpośrednim wpływem mediów na kształt widowiska scenicznego - przyjrzeć się obrazowi teatru w Polsce, który prezentowany jest tak zwanej „opinii publicznej” przez środki masowego przekazu. Za punkt wyjścia przyjmuję medialną kategorię newsa. To ona ma decydujaccy wpływ na odbiór konkretnych, wspominanych niżej, wydarzeń teatralnych. Niezależnie od rangi artystycznej zyskały one szeroki rozgłos medialny, wpływając na teatralną świadomość Polaków. Uznanie znaczenia postprawdy, podobnie jak odniesienie do „wojen nieprzeżytych” w przywołanym wyżej cytacie z tekstu Agnieszki Jakimiak i Weroniki Szczawińskiej, upoważnia do eksponowania roli i znaczenia emocji. Podobnie jak Małgorzata Trofimiuk, która wypowiadała cytowane powyżej słowa w spektaklu Weroniki Szczawińskiej na scenie Teatru Polskiego w Bydgoszczy, chciałbym skupić się na zadawaniu pytań, nie udzielając na nie odpowiedzi. W erze postprawdy do rozstrzygania potencjalnych wątpliwości niepotrzebne jest bowiem oparcie w faktach. Na każde z postawionych pytań odpowiadać można indywidualnie i zgodnie z własną intuicja - niezależnie od posiadanych kompetencji, doświadczeń i wiedzy. Wystarczy jedynie wewnętrzne przekonanie, jednostkowe emocje lub wiara.

Pierwsze pytania odnoszą się do spektaklu wystawionego w roku 1999 i będącego jednym z wydarzeń, które w praktyce polskiego teatru wyznaczaja granicę współczesności ${ }^{18}$. Czy podczas prezentacji Shopping and Fucking Marka Ravenhilla w reżyserii Pawła Łysaka, jak twierdziła część publiczności - na czele z warszawskimi i poznańskimi radnymi miejskimi - na scenie

ska, Pod okupacja mediów, Warszawa 2014; Teatr wśród mediów, red. A. Duda, M. Wiśniewska, B. Oleszek, Toruń 2015; a także: P. Auslander, Liveness. Performance in a Mediatized Culture, London-New York 2008; S. Dixon, Digital Performance. A History of New Media in Theater, Dance, Performance Art, and Installation, Cambridge-London 2007.

${ }^{18}$ Argumenty dla takiego traktowania polskiej prapremiery Shopping and Fucking Marka Ravenhilla w reżyserii Pawła Łysaka w kontekście krzepnącego w kraju liberalnego kapitalizmu przywołane zostały w tekście P. Dobrowolski, Przekupnie w światyni. Przestrzeń handlu $i$ wymiany ukazana na teatralnej scenie, [w:] Przestrzenie we wspótczesnym teatrze $i$ dramacie, red. V. Sajkiewicz i E. Wąchocka, Katowice 2009, s. 135-151. 
Teatru Rozmaitości dochodziło do „homoseksualnej orgii”19? W cytowanym przez prasę oświadczeniu warszawskich samorządowców klubu AWS wyrażana jest „dezaprobata” wobec „przekraczania granic swobody twórczej, która [...] polega na realizmie kloacznym - z drastycznymi scenami gwałtów homoseksualnych, obscenicznym słownictwem i upokarzajacymi człowieka zachowaniami" ${ }^{20}$. Medialne doniesienia na temat kolejnych pokazów Shopping and Fucking nierozerwalnie łączyły się z komentarzami wyrażającymi sprzeciw wobec prezentacji tego widowiska. Przetwarzały one i powtarzały cytowane tu opinie krytyczne, nie wzbogacając wiedzy potencjalnych widzów o spektaklu. A jednak stanowiły podstawowe źródło powszechnej wiedzy na temat budzącego kontrowersje przedstawienia.

Szerokiej opinii publicznej w podobny sposób - jako spektakl nieprzyzwoity i promujący degenerację - prezentowana była Śmierć $i$ dziewczyna z wrocławskiego Teatru Polskiego. Abstrahując od promocyjnych i politycznych intencji wpływających na postępowanie reżyserki Eweliny Marciniak i dyrektora wrocławskiej sceny Krzysztofa Mieszkowskiego, warto zadać pytanie, czy sama zapowiedź udziału zaproszonych z zagranicy „aktorów” pornograficznych, nawet jeśli na scenie rzeczywiście mieli odbyć (a nie markować) heteroseksualny stosunek seksualny, uzasadnia ekspresję oburzenia wobec „pornografii w rozumieniu pełnym i dosłownym” ${ }^{21}$, do której sprowadzana była, inspirowana twórczością Elfride Jelinek, produkcja teatralna. Medialne informacje wystarczyły, by wicepremier polskiego rządu, minister kultury Piotr Gliński, jeszcze w trakcie prób, przed pierwszą oficjalna prezentacją spektaklu, formułował żądania „wstrzymania przygotowań premiery w zapowiadanej postaci, łamiącej powszechnie przyjęte zasady współżycia społecznego"22. Oficjalne stanowisko kierowanego przez niego resortu, po zapowiedzi, że „MKiDN nie zamierza ingerować w wolność wypowiedzi artystycznej” oraz „nie zamierza [...] dazżyć do wprowadzania

19 „Prezentacje orgii homoseksualnej w murach Teatru Polskiego nie powinny mieć miejsca - mówił Krzysztof Mączkowski - Uważam, że obydwaj panowie dyrektorzy prezentują spektakle skandaliczne, bo nie stać ich na prezentację poważnego repertuaru”. MARK, Klaskałem z grzeczności, „Gazeta Poznańska” 2001, nr 98 (26.04.2001).

${ }^{20}$ OSA, DOW, Przeciw (ob)scenie, „Gazeta Wyborcza - Gazeta Stołeczna” 1999, nr 120 (25.05.1999).

${ }^{21}$ Taki zwrot znalazł się w liście Wojciecha A. Kwiatkowskiego, dyrektora Departamentu Finansowego Ministerstwa Kultury i Dziedzictwa Narodowego do Cezarego Przybylskiego, marszałka województwa dolnośląskiego, który zawierał oficjalne stanowisko ministerstwa w związku z przygotowywaną premiera spektaklu. Cytat za: <http://www.e-teatr.pl/pl/artykuly/212824,druk.html> [dostęp: 1.10.2018].

${ }^{22}$ DOCZ, AS, MAGA, Cenzura w Teatrze Polskim? Minister każe wstrzymać przygotowania do premiery spektaklu „Śmierć i dziewczyna”, „Gazeta Wyborcza <http://wroclaw. wyborcza.pl/wroclaw/1,35771,19222568,cenzura-w-teatrze-polskim-minister-kaze-wstrzymac-przygotowania.html\#ixzz4Vdu8LHJo> [dostęp: 1.10.2018].

173 Scena prawdy dyskursywnej i postprawdy 
jakichkolwiek form cenzury”, zawierało oczekiwanie, że „Pan Marszałek $\mathrm{w}$ trybie natychmiastowym nakaże wstrzymanie przygotowań premiery w zapowiadanej postaci, łamiącej powszechnie przyjęte zasady współżycia społecznego"23. Temat przygotowywanego przez Ewelinę Marciniak spektaklu przez kilka dni pozostawał gorącym medialnym newsem, prowokując do wypowiadania się na temat powinności teatru i oczekiwań wobec tej sztuki wiele osób na co dzień w żaden sposób niezwiązanych ze scena, jak poseł Ryszard Petru ${ }^{24}$ czy Marta Kaczyńska, felietonistka tygodnika „wSieci”25.

W ostatnich dniach września 2016 roku, podczas Festiwalu Prapremier w Bydgoszczy, w ogólnopolskich i lokalnych mediach pojawiły się głosy oburzenia, odnoszące się do zaprezentowanego 25 września na dużej scenie Teatru Polskiego spektaklu Olivera Frijića. Dziennik „Fakt” na pierwszej stronie opublikował duże zdjęcie z Naszej przemocy i waszej przemocy, dopełnione krzykliwym, rzucającym się w oczy nagłówkiem: „Zrobili z Jezusa gwałciciela. Minister kultury dał 250 tys. zł na tę ohydę"26. Czy rzeczywiście w czasie tego widowiska znieważono polską flagę i obrażono uczucia religijne polskich katolików, a minister, wspierający dotacją organizację festiwalu, dał pieniądze właśnie na wskazaną w artykule prezentację? A może podczas spektaklu dokonano celowej manipulacji wrażeniami i opiniami widzów, podsuwając im obrazy łatwo poddające się nadinterpretacji, jak w swoim tekście komentującym całe zajście zasugerował Stanisław Godlewski ${ }^{27}$ ? Jeśli tak, to manipulacji tej ulegli nie tylko dziennikarze, duchowni i politycy publicznie wyrażający dyktowane emocjami opinie, ale także bydgoska prokuratura, która zdecydowała się wszcząć dochodzenie w tej sprawie.

W bardzo podobny sposób interpretować można mechanizm, który wywoływał i wywołuje oburzenie w odniesieniu do innego, tym razem wyprodukowanego i zrealizowanego w Polsce, na scenie Teatru Powszechnego im. Zygmunta Hübnera w Warszawie, spektaklu Frijića - Klatwy, opartej na motywach z dramatu Stanisława Wyspiańskiego. Czy podczas tego przedstawienia dokonuje się „publiczna profanacja krzyża” i ,znieważanie osoby św. Jana Pawła II", na co wskazywał w specjalnym oświadczeniu kardynał Stanisław Dziwisz, sugerując, że to widowisko jest doświadczeniem „szcze-

${ }^{23}$ Oficjalny list z Departamentu Finansów Ministerstwa Kultury i Dziedzictwa Narodowego, adresowany do marszałka województwa dolnośląskiego Cezarego Przybylskiego (20.11.2015); <http://www.mkidn.gov.pl/media/_img/content2015-2/20151120_tp.pdf> [dostęp: 1.10.2018].

${ }^{24}$ Informacja PAP z 23.11.2015, <http://www.e-teatr.pl/pl/artykuly/212865.html> [dostęp: 1.10.2018].

${ }^{25}$ M. Kaczyńska, Spektakl, „wSieci” 2015, nr 46 (16.11.2015).

${ }^{26}$ „Fakt. Gazeta Codzienna”, 29.09.2016.

${ }_{27}$ S. Godlewski, Po raz drugi - co widzimy?, <http://www.e-teatr.pl/pl/artykuly/230113. html> [dostęp: 1.10.2018]. 
gólnie bolesnym dla wszystkich wierzacych Polaków"28? Takie i wiele podobnych wypowiedzi sprowokowały masowy ruch sprzeciwu wobec tej produkcji, dyrekcji i całego Teatru Powszechnego, łącznie z aktorami biorącymi udział w spektaklu. Medialna postprawda, dominująca w dyskusji na temat Klatwy, wpłynęła na społeczny odbiór tego widowiska i prezentującej go instytucji, ale także całej instytucji teatru, a nawet - widzianej ogólnie - instytucji sztuki w Polsce. Postprawda w decydujący sposób kształtuje relacje pomiędzy sztuką (artystami i ich dzianiami) a społeczeństwem.

Kiedy za miarę popularności wydarzenia artystycznego uznamy to, ile (niezależnie od treści) o czymś mówi się lub pisze, cztery wskazane spektakle należą do ścisłej czołówki najbardziej popularnych widowisk teatralnych ostatniego ćwierćwiecza w Polsce. Do tak zdefiniowanego zbioru trzeba dołączyć jeszcze jedno, choć w naszym kraju nikt nie miał okazji zobaczyć go osobiście. Prezentacja inscenizacji Golgoty Picnic Rodriga Garcíi w poznańskim Centrum Kultury Zamek miała odbyć się w dniach 27 i 28 czerwca 2014 roku. Spektakl ten, zaplanowany w programie Malta Festival Poznań 2014 - jak sugerował ówczesny prezydent Poznania Ryszard Grobelny, celnie stosując kategorię postprawdy, zanim samo słowo zyskało światowa popularność - stanowił realne zagrożenie dla „poznańskich wartości”, których poszanowania się domagał29. A skoro pojawiło się zagrożenie, ktoś musiał mu się przeciwstawić. Czy zadania tego gotowa była podjąć się zaangażowana politycznie, konserwatywna młodzież i patriotyczni, jednoczący się ponad podziałami, kibice - na co dzień zantagonizowanych - klubów sportowych ${ }^{30}$ ? Jak stwierdził komendant miejskiej policji w Poznaniu, w planowanej manifestacji przeciwko prezentacji spektaklu Garcíi miało wziąc udział 50 tysięcy osób gotowych czynnie i biernie blokować Centrum Kultury Zamek, gdzie zaplanowane zostały pokazy Golgoty Picnic. Nigdy nie skonfrontowano tych zapowiedzi z rzeczywistościa. Wobec politycznych nacisków i deklarowanej bezradności policji dyrektor Malty Michał Merczyński zrezygnował z prezentacji spektaklu. Wydaje się, że zarówno on, jak i przedstawiciele służb porządkowych ulegli wpływowi medialnej postprawdy, swoje sądy opierając na liczbie wpisów na forach internetowych i nadsyłanych do Fundacji Malta wiadomości mailowych z pogróżkami kierowanymi do jej pracowników.

${ }^{28}$ Kard. Dziwisz: Szczególny ból sprawito mi ohydne poniżenie osoby św. Jana Pawła II, „Do Rzeczy” 23.02.2017, <https://dorzeczy.pl/kraj/22773/Kard-Dziwisz-Szczegolny-bol-sprawilo-mi-ohydne-ponizenie-osoby-sw-Jana-Pawla-II.html> [dostęp: 1.10.2018].

${ }^{29}$ Picnic Golgota Polska. Sztuka - religia-demokracja, red. A. Adamiecka-Sitek, I. Kurz, Warszawa 2015, s. 72. Na wspomniany tom składa się kalendarium wydarzeń związanych z odwołanym spektaklem Garcíi, dotyczące ich opinie i analizy.

${ }^{30}$ Wspominano kibiców Ślasska Wrocław, Lechii Gdańsk i Lecha Poznań, tamże, s. 71.

175 Scena prawdy dyskursywnej i postprawdy 
Wymienione tu przykłady zachęcają do postawienia pytania o to, na jakich zasadach można przyjmować za pewnik coś, co znamy tylko z zapośredniczonych przekazów, relacji i reprezentacji. Czy prawda dotycząca teatru, podobnie jak scena prawdy w granicach teatru jako instytucji artystycznej prezentacji, ma charakter dyskursywny? Wspomniane sytuacje, które prowokowały liczne głosy oburzenia, polaryzowały krytyków i miłośników teatru, ale wpływały też na całe społeczeństwo polskie, przypominaja o założeniach i wnioskach bestselleru Pierre'a Bayarda - Jak rozmawiać o ksiażkach, których się nie czytato? Na wstępie tej książki jej autor mówi wprost, że „często wręcz łatwiej nam mówić o takiej lub innej książce, jeśli jej nie przeczytaliśmy w całości lub zgoła nigdy do niej nie zajrzeliśmy" ${ }^{1}$, niż o takiej, którą dobrze znamy. Na podobnej zasadzie - z łatwościa przychodzi nam formułowanie zdecydowanych sądów na temat niezobaczonych spektakli teatralnych, nieprzeżytych wojen, powstań, w których nie braliśmy udziału, strajków, w których nie uczestniczyliśmy i wielu innych wydarzeń, których nie doświadczyliśmy bezpośrednio. Mimo to gotowi jesteśmy przekonywać potencjalnych oponentów, że wiemy na ich temat wszystko. Postprawda jest kategoria, która znalazła swoje miejsce także w najnowszej historii teatru polskiego, na którą wywarła trwały wpływ.

\section{Doświadczenie}

Badający Wojny Nieprzeżyte powinni nasłuchiwać albo przypominać sobie, co wysłyszeli. Powinni wypatrywać albo przypominać sobie, co przewidzieli.

Powinni analizować, algorytmować, animować doświadczenia i unikać ambiwalencji. A następnie przedstawiać swoje badania w angażujący sposób ${ }^{32}$.

Po przemianach ustrojowych roku 1989 w kręgu polskich krytyków, teoretyków i artystów powracały postulaty, by sztuka podejmowała próby odzwierciedlenia zmian, którym ówcześnie podlegała rzeczywistość. W obszarze twórczości teatralnej i dramatycznej na realizację tego dążenia trzeba było poczekać około dekady. Na przełomie wieków kilka zbieżnych inicjatyw w obszarze literatury teatralnej zainicjowało nową tendencję realistyczna. Początek szczytowej fazy tego okresu znaczyło założenie w roku 1998 towarzystwa teatralnego (Paweł Wodziński i Paweł Łysak, którzy określali swoją inicjatywę mianem ,pierwszego impresaryjnego teatru współczesnego dramatu", chcieli, żeby nazwa ta pisana była małą litera), a pięć lat później

${ }^{31}$ P. Bayard, Jak rozmawiać o ksiażkach, których się nie czytało?, przeł. M. Kowalska, Warszawa 2008, s. 8.

${ }^{32}$ A. Jakimiak, dz. cyt. 
domknęło powołanie przez Tadeusza Słobodzianka Laboratorium Dramatu (którego charakter współokreślało istniejące równolegle Laboratorium Reportażu UW) działającego wówczas przy Teatrze Narodowym w Warszawie i wydanie „pierwszej antologii polskiego dramatu opublikowanej od lat 80.”33.

Roman Pawłowski we wstępie do tego zbioru stwierdził, że „około 2000 roku pojawiła się fala nowych, wartościowych polskich dramatów”34, których znaczenie określał, odnosząc się do szekspirowskiej koncepcji „zwierciadła natury" ${ }^{35}$. Tymczasem wartość dokumentacyjna tekstów zaprezentowanych w Pokoleniu porno i innych niesmacznych utworach teatralnych sprowadzała się do naśladowania uwarunkowań medialnych przedstawianego w nich świata ${ }^{36} \mathrm{i}$ do użycia w dialogach języka, który naśladował język ówczesnych przedstawicieli portretowanych grup społecznych. I chociaż w zbiorze tym pojawiały się też dramaty biorące zjawisko mediatyzacji w ironiczny cudzysłów, jako najtrafniej charakteryzujące praktykę pisania dla teatru na przełomie wieków jawią się te, w których pojedyncze fakty medialne obrastały materia poważnej fikcji dramatycznej ${ }^{37}$.

Monika Wasilewska, z powodzeniem podejmując próbę krytycznej analizy wyboru Pawłowskiego, stwierdziła, że zamieszczone w nim utwory odchodzą od dramatycznej koncepcji dramatu na rzecz praktyki deskryptywnej. Tym samym zbliżaja się do zaproponowanego przez Denisa Diderota konceptu tableau ${ }^{38}$. Badaczka określiła je więc jako „neonaturalistyczne”. Sam Roman Pawłowski przez kolejną dekadę nie zmodyfikował formułowanych przez siebie oczekiwań wobec tekstu teatralnego. Dokonał jednak zmiany

${ }^{33}$ A. Dąbek, Dramat na papierze, „Dwutygodnik” 2012, nr 77, <http://www.dwutygodnik. com/artykul/3235-dramat-na-papierze.html> [dostęp: 1.10.2018].

${ }^{34}$ R. Pawłowski, Wstęp, [w:] Pokolenie porno i inne niesmaczne utwory teatralne, wybór R. Pawłowski, red. H. Sułek, Kraków 2003, s. 5.

${ }^{35}$ W. Szekspir, Hamlet, akt III scena II, przekład Macieja Słomczyńskiego. Nawiązanie do Hamleta obecne jest także w motcie do zbioru: „Dramaty to krótka, ale pełna treści kronika naszych czasów”, R. Pawłowski, dz. cyt., s. 5.

${ }^{36}$ Dowiódł tego Przemysław Czapliński w roku 2003, omawiając krytycznie twórczość brutalistów na łamach „Gazety Wyborczej”. P. Czapliński, Socjoza, „Gazeta Wyborcza”, 1516 lutego 2003.

${ }^{37} \mathrm{~W}$ Eucji i jej dzieciach Marka Pruchniewskiego faktograficzne źródło fabuły stanowi jeden z pierwszych nagłośnionych przez polskie środki masowego przekazu przypadek dzieciobójstwa, do którego doszło we wsi Wrotnowo w okolicy Siedlec (ukrywającej zwłoki własnych dzieci w niebieskich plastikowych beczkach, które widziała cała Polska dzięki zdjęciom w „Wiadomościach” TVP1). Natomiast kontekstem Zabij ich wszystkich Przemysława Wojcieszka są zamieszki w Słupsku po zabójstwie 13-letniego Przemka Czai w 1998 roku. Chłopiec zmarł po kilkakrotnym uderzeniu pałką przez policjanta w chwilę po tym, jak razem z grupa kibiców przeszedł ulicę na czerwonym świetle.

${ }^{38}$ M. Wasilewska, Dramat polski w wyborach Romana Pawłowskiego. Bliżej Zoli niż Lehmanna, [w:] Dramat made (in) Poland. Wspótczesny dramat polski we wspótczesnej polskiej rzeczywistości, red. W. Baluch, Kraków 2009. 
środka przekazu i w sezonie teatralnym 2012/2013 stał się współtwórca wyreżyserowanego przez Marcina Wierzchowskiego cyklu Jeżyce story. Posłuchaj miasta! Jego cztery części były prezentowane na scenie poznańskiego Teatru Nowego jako specyficzny „,serial teatralny”. Tekst sceniczny tej prezentacji nie odwoływał się do medialnych newsów. Wypowiadający go aktorzy kontekstualizowali fragmenty zebranych przez siebie opowieści mieszkańców jednej z dzielnic Poznania - tytułowych Jeżyc. Wykorzystywane w kolejnych częściach cyklu wypowiedzi zawierały subiektywne sądy i opinie przeplatane prognozami demograficznymi i legendami miejskimi. Historie z przeszłości łączyły się z przywoływanymi problemami lokatorskimi i informacjami o nowych inwestycjach. Pogmatwane losy miejsc, ludzi i zwierząt łączyły się w sceniczne opowieści przypominające reportaż.

Pawłowski, dramaturg całego cyklu, zastosował technikę verbatim, w której teatr zbliża się do dokumentu widzianego jako „twórcza interpretacja rzeczywistości" ${ }^{39}$. Spektakl, przytaczając cudze opowieści, sądy i opinie, ukazuje alternatywne punkty widzenia świata i wzbogaca doświadczenia widzów o perspektywę Innego. Gra aktorów może być wzorowana na zachowaniu i sposobie wypowiadania się bohatera opowieści, tworząc rodzaj jego dramatyzowanego sobowtóra. Pawłowski opisywał „prosta” - jak sam ją nazywał - receptę na stworzenie scenariusza takiego widowiska teatralnego, formułując konkretne wskazówki: „Nagraj lub zapamiętaj opowieść znajomego, na przykład o tym, jak poznał miłość swego życia, wybierz najważniejsze wątki, a następnie powtórz słowo w słowo ze sceny. Spróbuj naśladować jego sposób mówienia, pauzy, charakterystyczne gesty. Nie musisz wszystkiego kopiować, wystarczy kilka cech, które pozwolą widzowi zobaczyć w Tobie - bohatera. To wszystko - masz verbatim" ${ }^{40}$.

Czy verbatim, jako gatunek teatralny, bliższy jest kategorii prawdy czy postprawdy? Kiedy realizatorzy spektaklu oddaja głos jego bohaterom, pozwalając im wypowiadać własne sądy i opinie, dopuszczają możliwość zdominowania prezentowanego dyskursu przez subiektywna, uznawana przez jednostkę, wizję świata. Rama fikcjonalności, typowa dla teatralnego przedstawienia (scenografia, światła, projekcje) i rozpoznawalne techniki aktorskie prowokują dodatkowy dystans odbiorców wobec prezentowanych opowieści. Prawda wzbogacona zostaje w ten sposób przez jednostkowe doświadczenie, zyskując status postprawdy. Przekroczona zostaje granica, która przypomina o różnicach pomiędzy klasycznym reportażem i reportażem w stylu

${ }^{39}$ Definicja filmu dokumentalnego sformułowana w roku 1926 przez Johna Griersona, za: J. Grierson, The first principles of documentary, [w:] Grierson on Documentary, ed. F. Hardy, London 1966, s. 147.

${ }^{40}$ R. Pawłowski, Co to jest verbatim?, <http://www.jezycestory.pl/jezycestory/Verbatim. html> [dostęp: 06.06.2016]. 
gonzo, w którym subiektywne obserwacje i opinie mieszają się z fantazjami autora $^{41}$. Gonzo, będące specyficznym wcieleniem dokumentalnego gatunku literackiego, nie powróciło do świadomości polskich czytelników za sprawa swoich amerykańskich pierwowzorów, a prozy Ziemowita Szczerka, którego książki z powodzeniem inscenizowane są również na teatralnych scenach ${ }^{42}$.

Specyficzną formę teatru verbatim wykorzystuje spektakl Spisek smoleński. Lech Raczak rozpoczął pracę nad tekstem jego scenariusza rok po wydarzeniach z 10 kwietnia 2010 roku. Inspirowały go nawarstwiające się mity na temat katastrofy prezydenckiego samolotu. Wciąż powracające hipotezy i domniemania sprawiły, że tragedia pod Smoleńskiem nadal postrzegana jest jako zbiór możliwych, alternatywnych wersji zdarzeń prowadzących do tragicznego finału. Podczas wyreżyserowanego przez Raczaka „teatralnego seansu spirytystyczno-teatralnego" aktorzy wywołują upiora teorii spiskowych. Odgrywają sytuacje, które są niepotwierdzonymi spekulacjami, ale co jakiś czas pojawiają się jako znaczące elementy debaty publicznej. W spektaklu zostają one zaprezentowane jako możliwe przyczyny katastrofy prezydenckiego TU-154M: aktorzy wnoszą fałszywe radiolatarnie, rozpylona zostaje mgła, a kontrolerzy z lotniska Siewiernyj sa pijani. Mowa o bąblu gazowym i „bombie izowolumetrycznej” , wniesionej na pokład samolotu pod postacia gaśnicy”. Prezentowana jest nawet treść - wywołującej do dzisiaj wiele domysłów - rozmowy telefonicznej pomiędzy braćmi Kaczyńskimi. Spisek smoleński nie jest spektaklem o katastrofie, a o narracjach, którymi od pierwszego dnia obrastała ona w zbiorowej wyobraźni.

Do scenariusza Spisku włączone zostały cytaty z zasłyszanych lub wyczytanych na internetowych forach i w prasie wypowiedzi współtworzących teorie spiskowe, sądy wypowiadane przez polityków i opinie samozwańczych specjalistów od katastrof lotniczych. Spektakl staje się w ten sposób sceniczną prezentacją jednego z najpopularniejszych współczesnych polskich mitów. Lech Raczak nie pozostaje wobec niego bezkrytyczny. Dlatego właśnie punktem kulminacyjnym jego przedstawienia nie jest sama katastrofa, a późniejsze wydarzenia na Krakowskim Przedmieściu, gdzie niektórzy zyskali wiarę, pozwalająca dowodzić przyczyny tragicznych wydarzeń, a innipretekst do żartów. Spektakl Raczaka i prowadzonego przez niego Teatru Orbis Tertius prezentuje rodząca się prawdę na temat zamachu z subiektywnej perspektywy teorii spiskowych, wiary i postprawdy.

${ }^{41}$ E. Żyrek-Horodyska, Od amerykańskiego snu Thompsona po ukraiński Mordor Szczerka. Estetyzacja świata w duchu gonzo, „Konteksty Kultury” 2017, nr 14, z. 2, s. 217-232.

${ }^{42}$ Z. Szczerek, Przyjdzie Mordor $i$ nas zje, czyli Tajna historia Stowian, adaptacja M. Kmiecik, reż. R. Brzyk, Teatr im. Juliusza Osterwy, Lublin, premiera 14.03.2015; Z. Szczerek, Siódemka, adaptacja M. Kmiecik, reż. R. Brzyk, Teatr Zagłębia, Sosnowiec, premiera 2 kwietnia 2016. 


\begin{abstract}
Aktor
Z uwagi na niefortunność materiału staram się odnaleźć, w repertuarze mych cielesnych środków, odpowiedni do sytuacji tryb zachowania.

Najpierw angażuję twarz, mając nadzieję na stosowny wyraz.

Włączam też głos, zawsze dobrze powiedzieć coś w rodzaju „to niebywałe ${ }^{43}$.
\end{abstract}

Wyreżyserowany przez Rabiha Mroué na scenie Teatru Polskiego w Bydgoszczy spektakl Tu Wersalu nie będzie wykorzystuje spekulacje medialne, z różnych perspektyw opowiadając o śmierci Andrzeja Leppera. Pojawiają się w nim, wzorowane na stylistyce dyskursu prasowego, rzeczywiste, opublikowane w polskich gazetach wypowiedzi mające charakter newsów. Rolę nie mniej ważną od tekstu spełnia także, ujawniający swoją podmiotowość, aktor: „Szanowni Państwo. Nazywam się Janek Sobolewski i jestem aktorem. Zostałem wybrany do tego projektu dlatego, że trzy lata temu, zaraz po skończeniu szkoły teatralnej, próbowałem popełnić samobójstwo, ale to mi się nie udało" ${ }^{44}$. Otwierające bydgoski spektakl słowa brzmią dramatycznie, jednak dalsza część tekstu Sobolewskiego diametralnie zmienia wrażenie, że widzowie są świadkami osobistego wyznania aktora: „Skoczyłem z najwyższego budynku w okolicy. Na wysokości drugiego i trzeciego piętra poczułem zapach mielonego. Możecie się państwo śmiać, ale to mnie uratowało".

Po chwili, znów oscylując na granicy pomiędzy rolą a realnością własnej obecności, Sobolewski-postać wyznaje, że od czasu próby targnięcia się na swoje życie w szczególny sposób interesuje się samobójstwami. Obsesja na ich punkcie doprowadziła go do Andrzeja Leppera i sprawia, że stojąc przed publicznościa, chce przeprowadzić sceniczne śledztwo w sprawie jego śmierci. Po tak sformułowanej deklaracji wskazuje leżące po jednej stronie przestrzeni scenicznej gazety i kopie ich wybranych stron: „Wszystkie materiały zgromadzone tutaj wskazują na to, że Andrzej Lepper popełnił samobójstwo”. Potem zwraca się ku drugiej stronie sali: „Wszystkie materiały tutaj wskazują na to, że Andrzej Lepper został zamordowany”. Janek Sobolewski podnosi gazety i czyta na głos fragmenty artykułów. Każdy z nich wydaje się stworzony specjalnie na potrzeby spektaklu. Sa jednak „prawdziwe” - zarówno za życia, jak i po śmierci Andrzeja Leppera w prasie i w Internecie pojawiły się przeróżne teorie dotyczące jego osoby i politycznej kariery. Niektóre z nich sugerowały, że wiedział zbyt wiele, zatem jego

${ }^{43}$ A. Jakimiak, dz. cyt.

${ }^{44}$ Ten i kolejne cytaty pochodzą ze scenariusza spektaklu Rabiha Mroué, Tu Wersalu nie będzie, Teatr Polski im. Hieronima Konieczki w Bydgoszczy, premiera 18 czerwca 2016. Maszynopis udostępniony dzięki uprzejmości Teatru Polskiego im. Hieronima Konieczki w Bydgoszczy. 
pozycja mogła zagrażać wysoko postawionym przedstawicielom biznesu i polityki. Sugerowano jego zaangażowanie w sprawy międzynarodowe. Podważano tezę o samobójstwie, którego - jako chłop - nie mógłby podobno dokonać w czasie żniw (umarł 5 sierpnia 2011 roku). Śmierć Andrzeja Leppera łączono z rusztowaniem stojącym zastanawiająco długo przy budynku, w którym mieściło się biuro jego partii. To po nim miał wejść zabójca, który jakoby użył gazu, a następnie powiesił polityka. Chociaż - niejednokrotnie zaprzeczające sobie nawzajem - cytowane przez Sobolewskiego nagłówki i treści wydają się wnosić ładunek fikcji, teatralna publiczność nie ma pewności, czy w trakcie spektaklu obcuje z prawda, fantazją czy z postprawda.

Sytuacja okazuje się szczególnie ciekawa, kiedy oddziaływanie na widzów z poziomu przekazywanych treści - użycie całego repertuaru „faktów medialnych" - wzbogacone zostaje przez fizyczne warunki aktora. W trakcie tego spektaklu to Janek Sobolewski jest najważniejszym teatralnym medium, zdolnym przekazywać dowolne treści. To on jest narzędziem, nośnikiem ekspresji i źródłem niemal nieograniczonych możliwości tworzenia fikcji. A także realnie istniejącą osoba, która ma własną historię. Fenomenalna obecność aktora współtworzy w świadomości widzów realność roli, w której on występuje. Wykonawca przekracza tak ograniczenia warunkowane rzeczywistością pozaartystyczną. Znajduje się w przestrzeni liminoidalnej, w której medialna postprawda funkcjonuje w dwóch, równoległych odniesieniach: jako dramaturgiczna fikcja i teatralny autentyk.

Spektakl wyreżyserowany przez Rabiha Mroué należy do grupy widowisk teatralnych, w których przyjmowana rola ma decydujący wpływ na sposób postrzegania aktora przez widzów, a nie odwrotnie, co w teatrze zdarza się częściej. Przedstawienia wykorzystujące elementy metateatralności mogą bez straty dla własnej fikcjonalności proponować rozważania odnoszące się do problemów dotyczących ontologii scenicznych bytów. Przykładem takiego połączenia jest Ragazzo dell'Europa w reżyserii René Pollescha z TR Warszawa. Widowisko to było antycypacja kolejnej - szczególnie wyraźnej od sezonu 2014/2015 - fazy zwrotu autotematycznego w teatrze polskim. W Ragazzo jedna z postaci nawiąuje do filmu Karol - człowiek, który zostat papieżem, mówiąc o nim w kontekście obrazu Chopin. Pragnienie miłości. W obu główną rolę zagrał Piotr Adamczyk: „Wyobraź sobie taki kadr: FORTEPIAN I PIOTR ADAMCZYK. Natychmiast widzisz FRYDERYKA CHOPINA. Nie mogli tego pokazać! Po prostu nie mogli. Producent filmu Walseki nie mógł. Całymi nocami przewracał się z boku na bok, bo nie mógł tego pokazać. Jak zneutralizować Chopina w Adamczyku? Jak zneutralizować Chopina, kiedy już jest papieżem? Wymyślił. Przez 15 minut filmu Adamczyk gada o Chopinie. Recytuje Fortepian Szopena Norwi- 
da. Zamienili problem w żart. Zneutralizować Chopina w żart, bo inaczej widownia się pogubi”"45.

Wspomniane fabuły filmowe wymagały „neutralizacji” poprzednich wcieleń występującego w nich aktora. Autotematyczne spektakle teatralne - przeciwnie. Ewelina płacze Anny Karasińskiej, podobnie jak jej Drugi spektakl, Aktorzy żydowscy Anny Smolar, ale także wiele innych przedstawien, nawet jeśli oparte zostały na stabilnej ramie fikcjonalności (np. Wróg ludu Jana Klaty), stosuja technikę ujawniania podmiotowości biorących w nich udział aktorów. Ich obecność wykorzystywana jest przez twórców do poszukiwania prawdy. Dzieje się tak, ponieważ prawda pozostaje wciąż znaczącym elementem oczekiwań teatralnej widowni. Nawet dzisiaj, kiedy moc anihilującego jej znaczenie przedrostka post wydaje się nieograniczona.

Kreacja obrazu świata w sztuce za pomoca języka dyskursu medialnego nikogo dzisiaj nie dziwi. Zależna od sposobu formułowania przekazów i stylów ich odbioru względność komunikowanych treści wydaje się czymś oczywistym. Pogodziliśmy się z tym, że od przyjmowanego sposobu prowadzenia dyskursu zależy nie tylko obraz rzeczywistości, której wizja portretowana jest in statu nascendi, ale także osobistych historii konkretnych ludzi. Praktycznym wcieleniem zależności wizji prawdy i dyskursu jest tendencja do tworzenia jednostkowych konstruktów, mających charakter postprawdy. Wielokrotne powielanie i rozpowszechnianie hipotez, domysłów i kłamstw (w myśl wypowiedzi przypisywanej twórcy propagandowego sukcesu III Rzeszy, Josephowi Goebbelsowi) wystarczy, by „kłamstwo powtórzone tysiąc razy stało się prawdą". Opinię tę przywołała Joanna Krakowska w tekście do katalogu XXI Konfrontacji Teatralnych w Lublinie, zatytułowanym Auto-teatr $w$ czasach post-prawdy ${ }^{46}$, w którym zawarła sugestię, że autotematyzm stanowi bardzo znacząca szansę na ocalenie prawdy w przestrzeni sztuki teatru.

Podzielam to przekonanie, chociaż równocześnie zastanawiam się, czy teatrowi w ogóle potrzebna jest prawda. To sztuka, w której znakiem charakterystycznym zawsze było udawanie - markowanie, naśladowanie, tworzenie fikcji. Od wieków operowała iluzja, wykorzystując tęsknotę swojej widowni, jak Jarosław Fret łaknącej stabilnego oparcia w prawdzie.

${ }^{45}$ R. Pollesch, Ragazzo dell'Europa, na podstawie Capuccetto Rosso i Pabla w Markecie Plusa, przeł. D. Sajewska i H. Rogulska, scenariusz spektaklu TR Warszawa, premiera 26.05.2007. Maszynopis udostępniony dzięki uprzejmości TR Warszawa.

${ }^{46}$ J. Krakowska, Auto-teatr w czasach post-prawdy, „Dwutygodnik” 2016, nr 195, $<$ http://www.dwutygodnik.com/artykul/6756-auto-teatr-w-czasach-post-prawdy.html> [dostęp: 1.10.2018]. 
I podejmowała z nimi grę. Teatr wykorzystuje oczekiwania i nastawienie swojej publiczności, przekuwając je na własną korzyść. Osłabia przy tym wspomnianą tęsknotę, tworząc prezentacje rzeczywistości, które funkcjonują niczym „miękkie ostrze” opisane przez Paula Levinsona w kontekście technologii cyfrowej ${ }^{47}$. W diagnozie Levinsona znajomość kodów medialnych miała przyczyniać się do ulegania odbiorców demagogicznym zabiegom manipulujących nimi nadawców. Dzisiaj, w kolejnej fazie rozproszenia i uwieloznacznienia prezentowanej wizji świata, poszliśmy o krok dalej. Jednym z najważniejszych zadań współczesnej kultury (co nie jest wcale obserwacją nowa) jest uwieloznacznienie przekazu i władzy/wiedzy. Osłabia ono dominację konkretnych dyskursów i pokazuje, że możliwa nie jest jedna tylko perspektywa, sposób widzenia świata czy opisywania rzeczywistości. Taka właśnie rola mogłaby przypaść teatrowi jako sztuce, która zawsze (niemal zawsze, za wyjątkiem specyficznych stylistyk korzystających z doświadczeń happeningu czy invisible theatre Augusto Boala) prezentowana jest w ramie wprowadzającej fikcjonalność i zakładającej ja. To sztuka, która od zarania wiązała się z pojęciami gry, udawania, a często nawet - jawnego kłamstwa, wciagajac widza w przestrzeń afektów, wiary i przekonań, które prezentowana fikcję zamieniaja w postprawdę.

Zaistniałą sytuację - metaforycznie, ale też celnie - opisuje ostatni cytat z Wojen, których nie przeżyłam Agnieszki Jakimiak i Weroniki Szczawińskiej:

Badania prowadzone w moim departamencie przybierają formę, którą chętnie określam jako artystyczna. Nie waham się zaliczyć jej do sztuk wykonawczych, performatywnych, czy wręcz teatralnych. Jednym słowem: performance as research w odmianie wojennej ${ }^{48}$.

\section{BIBLIOGRAFIA}

Auslander P., Liveness. Performance in a Mediatized Culture, London-New York 2008. Bayard P., Jak rozmawiać o ksiażkach, których się nie czytało?, przeł. M. Kowalska, Warszawa 2008.

Błaszczak M., Ekrany i lustra w polskim dramacie współczesnym, Poznań 2009.

Chomsky N., Media Control. The Spectacular Achievements of Propaganda, New York 2002.

Dąbek A., Dramat na papierze, „Dwutygodnik” 2012, nr 77, <http://www.dwutygodnik. com/artykul/3235-dramat-na-papierze.html> [dostęp: 12.01.2017].

${ }^{47}$ P. Levinson, Miękkie ostrze, czyli Historia i przyszłość rewolucji informacyjnej, przeł. H. Jankowska, Warszawa 2006.

${ }^{48}$ A. Jakimiak, dz. cyt.

183 Scena prawdy dyskursywnej i postprawdy 
Dixon S., Digital Performance. A History of New Media in Theater, Dance, Performance Art, and Installation, Cambridge-London 2007.

Dobrowolski P., Przekupnie w światyni. Przestrzeń handlu i wymiany ukazana na teatralnej scenie, [w:] Przestrzenie we współczesnym teatrze i dramacie, red. V. Sajkiewicz, E. Wachocka, Katowice 2009, s. 135-151.

docz, as, maga, Cenzura w Teatrze Polskim? Minister każe wstrzymać przygotowania do premiery spektaklu „Śmierć i dziewczyna”, „Gazeta Wyborcza <http://wroclaw.wyborcza.pl/wroclaw/1,35771,19222568,cenzura-w-teatrze-polskim-minister-kaze-wstrzymac-przygotowania.html\#ixzz4Vdu8LHJo> [dostęp: 12.01.2017].

Donald Trump's file, <http://www.politifact.com/personalities/donald-trump> [dostęp: 12.01.2017].

Duda A., Performans na żywo jako medium i obiekt mediatyzacji, Toruń 2011.

„Fakt. Gazeta Codzienna”, 29.09.2016.

Fret J., Teatr - credo Jarostawa Freta, <http://www.wroclaw2016.strefakultury.pl/jaroslaw-fret> [dostęp: 1.10.2018].

Godlewski S., Po raz drugi - co widzimy?, <http://www.e-teatr.pl/pl/artykuly/230113. html> [dostęp 12.01.2017].

Grierson J., The first principles of documentary, [w:] Grierson on Documentary, ed. F. Hardy, London 1966.

Grotowski J., Świat powinien być miejscem prawdy, [w:] J. Grotowski. Teksty zebrane, Warszawa 2012, s. 618-623.

Jakimiak A., Wojny, których nie przeżyłam, scenariusz spektaklu w reżyserii Weroniki Szczawińskiej, Teatr Polski im. Hieronima Konieczki w Bydgoszczy, premiera 23.09.2015. Maszynopis udostępniony dzięki uprzejmości Teatru Polskiego w Bydgoszczy.

Kaczyńska M., Spektakl, „wSieci” 2015, nr 46 (16.11.2015).

Kard. Dziwisz: Szczególny ból sprawiło mi ohydne poniżenie osoby św. Jana Pawła II, „Do Rzeczy” 23.02.2017, <https://dorzeczy.pl/kraj/22773/Kard-Dziwisz-Szczegolny-bol-sprawilo-mi-ohydne-ponizenie-osoby-sw-Jana-Pawla-II.html> [dostęp: $01.10 .2018)$.

Krakowska J., Auto-teatr w czasach post-prawdy, „Dwutygodnik” 2016, nr 195, <http:// www.dwutygodnik.com/artykul/6756-auto-teatr-w-czasach-post-prawdy.html $>$ [dostęp: 12.01.2017].

Levinson P., Miękkie ostrze, czyli Historia i przyszłość rewolucji informacyjnej, przeł. H. Jankowska, Warszawa 2006.

Majmurek J., Post-prawda, czyli o świecie, $w$ którym ciagle można wierzyć $w$ zamach smoleński, <http://www.newsweek.pl/polska/spoleczenstwo/post-prawda-slowem-roku-2016-czym-jest-post-prawda-i-jak-wplywa-na-polityke-,artykuly,401583,1. html> [dostęp: 12.01.2017].

MARK, Klaskałem z grzeczności, „Gazeta Poznańska” 2001, nr 98 (26.04.2001).

Mroué R., Tu Wersalu nie będzie, Teatr Polski im. Hieronima Konieczki w Bydgoszczy, premiera 18.06.2016. Maszynopis udostępnionego dzięki uprzejmości Teatru Polskiego im. Hieronima Konieczki w Bydgoszczy.

Norman M., Whoever wins the US presidential election, we've entered a post-truth worldthere's no going back now, “The Independent Online", http://www.independent.co.uk/ 
voices/us-election-2016-donald-trump-hillary-clinton-who-wins-post-truth-worldno-going-back-a7404826.html> [dostęp: 1.10.2018].

OSA, DOW, Przeciw (ob)scenie, „Gazeta Wyborcza - Gazeta Stołeczna” 1999, nr 120 (25.05.1999).

Pawłowski R., Co to jest verbatim?, <http://www.jezycestory.pl/jezycestory/Verbatim. html> [dostęp: 18.07.2013].

Picnic Golgota Polska. Sztuka - religia - demokracja, red. A. Adamiecka-Sitek, I. Kurz, Warszawa 2015.

Pokolenie porno i inne niesmaczne utwory teatralne, wybór R. Pawłowski, red. H. Sułek, Kraków 2003.

Pollesch R., Ragazzo dell'Europa, na podstawie Capuccetto Rosso i Pabla w Markecie Plusa, przeł. D. Sajewska i H. Rogulska, scenariusz spektaklu TR Warszawa, premiera 26.05.2007. Maszynopis udostępniony dzięki uprzejmości TR Warszawa.

Ponczek E., Polityka wobec pamięci versus polityka historyczna: aspekty semantyczny, aksjologiczny i merytoryczny w narracji polskiej, „Przegląd Politologiczny” 2013, nr 2.

Post-truth politics. Art of the lie, "The Economist Online", <http://www.economist.com/news/leaders/21706525-politicians-have-always-lied-does-it-matter-if-they-leave-truth-behind-entirely-art?fsrc $=$ scn/tw/te/pe/ed/artofthelie $>$ [dostęp: 12.01.2017].

Sajewska D., Pod okupacja mediów, Warszawa 2014.

Szpunar M., Czym sq nowe media - próba konceptualizacji, „Studia Medioznawcze” 4 (35) 2008, s. 31-40.

Teatr wśród mediów, red. A. Duda, M. Wiśniewska, B. Oleszek, Toruń 2015.

Tesich S., A Government of Lies, „The Nation” 1992, January 6/13

Wasilewska M., Dramat polski w wyborach Romana Pawłowskiego. Bliżej Zoli niż Lehmanna, [w:] Dramat made (in) Poland. Wspótczesny dramat polski we wspótczesnej polskiej rzeczywistości, red. W. Baluch, Kraków 2009.

Word of the Year 2016 is..., <https://en.oxforddictionaries.com/word-of-the-year/word-of-the-year-2016> [dostęp: 12.01.2017].

Żyrek-Horodyska E., Od amerykańskiego snu Thompsona po ukrainski Mordor Szczerka. Estetyzacja świata w duchu gonzo, „Konteksty Kultury” 2017, nr 14, z. 2. 
